https://helda.helsinki.fi

\title{
How can we identify candidates at highest risk - to screen or not to screen?
}

Barengo, N. C.

2016

Barengo , N C \& Tuomilehto , J O 2016 , ' How can we identify candidates at highest risk - to screen or not to screen? ' , Herz , vol. 41 , no. 3 , pp. 175-+ . https://doi.org/10.1007/s00059-016-4417-5

http://hdl.handle.net/10138/223985

https://doi.org/10.1007/s00059-016-4417-5

publishedVersion

Downloaded from Helda, University of Helsinki institutional repository.

This is an electronic reprint of the original article.

This reprint may differ from the original in pagination and typographic detail.

Please cite the original version. 
Herz 2016 4 41:175-183

DOI 10.1007/s00059-016-4417-5

Published online: 6 April 2016

๑) Springer Medizin Verlag 2016

CrossMark

\author{
N. C. Barengo ${ }^{1,2} \cdot$ J. O. Tuomilehto ${ }^{1,3,4,5,6}$ \\ 1 Department of Public Health, Clinicum hallinto, University of Helsinki, Helsingin yliopisto, Finland \\ ${ }^{2}$ Herbert Wertheim College of Medicine, Florida International University, Miami, USA \\ ${ }^{3}$ Department of Chronic Disease Prevention, National Institute for Health and Welfare, Helsinki, Finland \\ ${ }^{4}$ Diabetes Research Group, King Abdulaziz University, Jeddah, Saudi Arabia \\ ${ }^{5}$ Dasman Diabetes Institute, Dasman, Kuwait \\ ${ }^{6}$ Centre for Vascular Prevention, Danube-University Krems, Krems, Austria
}

\title{
How can we identify candidates at highest risk - to screen or not to screen?
}

ulation carry genes that predispose to the development of T2D. Even though genetic effects are important for the development of the disease, it is not possible to modify them to prevent T2D. Dysglycemia is a progressive disorder; in people with IGT, approximately half develop T2D during a 10-year followup, and in Asian populations the rate of progression seems to be even faster [11-13]. It is important to understand that the risk of complications begins in the pre-diabetic phase, before blood glucose levels reach diagnostic cut-off points for, T2D resulting in significant morbidity and mortality from CVD [7, $14,15]$. With an increasing number of T2D patients worldwide, the number of patients with CVD will inevitably also rise. To avoid late complications of T2D and related costs, primary prevention of T2D itself and its early treatment are therefore necessary.

\section{Why screen people at a high risk of T2D?}

For disease prevention two approaches can be used: the population approach and the high-risk approach. The population approach does not require the identification of high-risk people, but preventive measures target the entire population, e.g. the promotion of physical activity. The high-risk approach starts with the identification of people at the high end of the risk distribution. The most efficient strategy in prevention is obviously the combination of these two approaches.

Obesity, unbalanced diet and physical inactivity are the major risk factors for diabetes. In people genetically predisposed to the disease, the probability of developing T2D is very high once exposed to unhealthy lifestyles. Fortunately, current scientific evidence from randomized controlled trials has revealed that the progression to T2D can be prevented or delayed in people with IGT by lifestyle intervention (• Tab. 1, [12, 13, 16-20]). The Finnish Diabetes Prevention Study (DPS) revealed that individualized counselling aimed at reducing weight, total intake of fat, and intake of saturated fat and increasing intake of fiber and physical activity, the risk of diabetes can be reduced by up to $58 \%$ compared with people with IGT who do not undergo any intervention [16]. A 6-year diet and exercise intervention was carried out in a clusterrandomized trial in Da-Qing, China, in 577 participants (mean age 45.0 years, mean BMI 25.8) with IGT were assigned either to the control, exercise alone, diet alone, or exercise plus diet groups [12]. The cumulative 6-year incidence of T2D was lower in each of the three intervention groups compared with the control group; the relative risk reduction in incidence was approximately $40 \%$ during the 6-year intervention period. The US Diabetes Prevention Program (DPP) ranlikely that more than half of the pop- 
Main topic

Tab. 1 Summary of lifestyle intervention trials in people with glucose metabolism disorders

\begin{tabular}{|c|c|c|c|c|c|}
\hline Author, year & Country & $\begin{array}{l}\text { Number } \\
\text { of partici- } \\
\text { pants }\end{array}$ & Intervention & $\begin{array}{l}\text { Follow-up } \\
\text { (years) }\end{array}$ & $\begin{array}{l}\text { Risk re- } \\
\text { duction of } \\
\text { lifestyle } \\
\text { modifica- } \\
\text { tion (\%) }\end{array}$ \\
\hline Pan et al., 1997 [12] & China & 530 & $\begin{array}{l}\text { Diet, physical } \\
\text { activity }\end{array}$ & 6 & 42 \\
\hline $\begin{array}{l}\text { Tuomilehto et al., } \\
2001 \text { [16] }\end{array}$ & Finland & 522 & $\begin{array}{l}\text { Diet, physical } \\
\text { activity }\end{array}$ & 3.2 & 58 \\
\hline $\begin{array}{l}\text { Knowler et al., } 2002 \\
\text { [17] }\end{array}$ & USA & 5234 & $\begin{array}{l}\text { Diet, physical } \\
\text { activity, met- } \\
\text { formin }\end{array}$ & 2.8 & 58 \\
\hline $\begin{array}{l}\text { Kosaka et al., } 2005 \\
\text { [18] }\end{array}$ & Japan & 458 & $\begin{array}{l}\text { Diet, physical } \\
\text { activity }\end{array}$ & 4 & 67 \\
\hline $\begin{array}{l}\text { Ramachandran et al., } \\
2006 \text { [13] }\end{array}$ & India & 531 & $\begin{array}{l}\text { Diet, physical } \\
\text { activity, met- } \\
\text { formin }\end{array}$ & 2.5 & 29 \\
\hline $\begin{array}{l}\text { Roumen et al., } 2008 \\
\text { [19] }\end{array}$ & $\begin{array}{l}\text { The } \\
\text { Nether- } \\
\text { lands }\end{array}$ & 147 & $\begin{array}{l}\text { Diet, physical } \\
\text { activity }\end{array}$ & 3 & 58 \\
\hline Penn et al., 2009 [20] & $\begin{array}{l}\text { United } \\
\text { Kingdom }\end{array}$ & 102 & $\begin{array}{l}\text { Diet, physical } \\
\text { activity }\end{array}$ & 3.1 & 55 \\
\hline Saito et al., 2011 [24] & Japan & 641 & $\begin{array}{l}\text { Diet, physical } \\
\text { activity }\end{array}$ & 3 & 44 \\
\hline
\end{tabular}

domized people with IGT and fasting glucose $\geq 95 \mathrm{mg} / \mathrm{d}$ to receive intensive dietary and exercise counselling, metformin, or placebo [17]. The relative risk reduction after 2.8 years of follow-up in the lifestyle intervention group compared with the placebo control group was $58 \%$, similar to the results from the DPS. The effect of lifestyle intervention was superior to that of metformin treatment, which showed a $35 \%$ relative risk reduction. Other studies such as the Indian DPP and the Japanese IT intervention trial revealed similar findings to those in the above-mentioned studies. All in all, the reduction in $\mathrm{T} 2 \mathrm{D}$ incidence in those trials varied between $29 \%$ and $67 \%$.

Lifestyle intervention in people with IGT during 4 years in the DPS induced sustaining lifestyle change and resulted in the long-term prevention of progression to type 2 diabetes (hazards ratio of T2D 0.61 compared with the initial control group) [21]. Moreover, the absolute risk reduction seemed to increase even after the actual lifestyle intervention program was ceased. Also, the participants with IGT who received a 6-year lifestyle intervention in the Chinese Da Qing study had a statistically significantly lower incidence of T2D two decades later com- pared with people of the control group [22]. During the 10-year overall followup of the US DPP Outcomes Study, the incidence of T2D in the original lifestyle intervention group remained lower than in the control group [23]. Thus, all three long-term follow-up studies of the clinical lifestyle intervention trials showed that adherence to lifestyle changes during the intervention period predicted a greater risk reduction during the total follow-up. It was estimated that lifestyle intervention needs to be provided for 6.4 high-risk individuals for an average of 3 years to prevent 1 case of diabetes.

At present, there are limited data to show whether progression from impaired fasting glucose (IFG) to T2D can be stopped by lifestyle intervention. The only clinical lifestyle trial that recruited people with IFG demonstrated a $59 \%$ relative risk reduction in people who had IFG and IGT combined, but failed to show any benefit with regard to T2D incidence in people who only had IFG [24]. Thus, there is convincing scientific evidence that treatment after early detection in people with IGT yields benefits superior to those obtained when treatment is delayed; T2D can be successfully prevented or its onset delayed in people with IGT, at least in a well-controlled clinical setting [24].

Considering the evidence presented above, it is important to identify people at a high risk of T2D, as they will benefit from early lifestyle changes with regard to the future development of T2D. Plasma glucose (fasting or $2 \mathrm{~h}$ after the Oral Glucose Tolerance Test, OGTT) and $\mathrm{HbAlc}$ testing are recommended methods for the diagnosis of T2D in the general population [25]. However, these are invasive, expensive and time-consuming procedures (especially the OGTT), and are hence not suitable as mass screening activities. Moreover, it has been commonly agreed that the detection of blood glucose at random in the population is not justified because glucose levels in the blood are highly variable [26]. The US recommendations have emphasized that fasting blood glucose may be less variable and more useful for screening purposes [25]. However, it has been revealed that the vast majority of early cases of asymptomatic T2D and IGT would not be detected by measuring fasting glucose alone [27, 28]. Therefore, a simple, rapid, and non-invasive score for identifying high-risk subjects is needed in primary care. A screening test is usually not diagnostic in itself, but in most cases is followed by appropriate invasive diagnostic tests to confirm the results. The screening process starts by selecting the target population, followed by a screening test to divide individuals into either apparently healthy or at-risk. For the apparently healthy individuals, regular screening at fixed relaxed 5- to 10year intervals is recommended. The atrisk people are referred for further evaluation and subsequent diagnostic, usually laboratory, investigations. Appropriate intervention is started among those with a confirmed risk status to reduce the risk of progression to T2D.

Several non-invasive tests have been developed as screening tools to assess the risk of T2D and to detect undiagnosed T2D. These include the American Diabetes Association (ADA) Risk Tools, the Finnish Diabetes Risk Score (FINDRISC), the National Health and Nutrition Examination Survey (NHANES) Risk Score, the Australian Diabetes Risk 
Hier steht eine Anzeige.

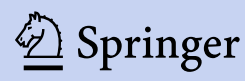


Score [29-38]. The Finnish Diabetes Risk Score (FINDRISC) is probably one of the most efficient screening tools. It is based on easily available information using eight parameters with categorized answers about age, body mass index (BMI), waist circumference, physical activity, daily consumption of fruit and vegetables, a history of antihypertensive drug treatment, a history of high blood glucose, and a family history of diabetes [29]. The total risk score value ranges from 0 to 26. The FINDRISC was shown to predict the 10-year risk of drug-treated T2D with a sensitivity of $78-81 \%$ and a specificity of $76-77 \%$. Furthermore, it detects prevalent asymptomatic T2D and other glucose metabolism disorders reasonably efficiently [39]. The FINDRISC was first validated in Italian and Greek populations with identical results [40, 41], was successfully applied in primary care in Barcelona, Spain [42], and was recommended in the guideline by the European Society for the Study of Diabetes and the European Society of Cardiology as a screening tool for T2D [43]. Recently, a European study validating existing non-laboratory-based models and assessing the variability in predictive performance in European populations found that existing diabetes prediction models can be used to identify individuals at a high risk of T2D in the general population [44]. Thus, screening tests for identifying people at a high risk of T2D are available and can detect the preclinical stage of the disease.

Almost 40 years ago, Wilson and Jungner attempted to define screening criteria to guide the selection of conditions that would be suitable for screening, based, among other factors, on the capacity to detect the condition at an early stage and the availability of an acceptable treatment [45]. They proposed that seven conditions have to be met to justify screening tests. In the case of screening for people at a high risk of T2D, there is convincing scientific evidence that screening for T2D fulfils the first five criteria proposed by Wilson and Jungner.

Herz 2016·41:175-183 DOI 10.1007/s00059-016-4417-5

(C) Springer Medizin Verlag 2016

N. C. Barengo · J. O. Tuomilehto

\section{How can we identify candidates at highest risk - to screen or not to screen?}

\section{Abstract}

Type 2 diabetes (T2D) causes a large economic and health-care burden globally. This article summarizes the benefits and unsolved questions of screening for T2D. Many T2D risk assessment tools have been developed. Furthermore, current evidence has shown that T2D can be prevented by lifestyle interventions, justifying T2D screening. However, information is scarce on the longterm impact of $\mathrm{T} 2 \mathrm{D}$ screening regarding health outcomes such as cardiovascular disease. Moreover, it is not certain whether health-care facilities and health-care staff are capable of implementing screening activities and subsequent interventions among high- risk individuals; lifestyle management tasks in particular are often not among the best skills that health-care personnel possess. Also, there is a lack of evidence for the periodicity of population-wide screening activities. As national health-care systems increasingly implement T2D screening, we may receive in the near future answers to some of our remaining research questions to fully assess the benefits and disadvantages of screening.

Keywords

Screening - Type 2 diabetes - Harms . Advantages - Disadvantages

\section{Wie können wir Personen mit dem höchsten Diabetesrisiko identifizieren - screenen oder nicht screenen?}

\section{Zusammenfassung}

Typ-2-Diabetes (T2D) ist eine große Belastung für die Wirtschaft und die Gesundheitssysteme weltweit. Dieser Artikel fasst die Vorteile und die ungelösten Fragen zum Screenen nach T2D zusammen. Bisher sind viele T2D-Risikobewertungsinstrumente entwickelt worden. Darüber hinaus haben aktuelle Forschungsergebnisse gezeigt, dass T2D durch Änderungen im Lebensstil vermieden werden kann, was das T2DScreening im Prinzip rechtfertigt. Allerdings gibt es kaum Informationen über die langfristigen Auswirkungen des T2DScreenings in Bezug auf gesundheitliche Auswirkungen, z. B. auf kardiovaskuläre Erkrankungen. Außerdem ist unklar, ob Gesundheitseinrichtungen und -personal in der Lage sind, die Screeningaktivitäten und die Folgemaßnahmen bei Personen mit hohem T2D-Risiko umzusetzen. Insbesondere Eingriffe in den Lebensstil zählen nicht zu den vorrangigen Aufgaben des Personals im Gesundheitswesen. Außerdem gibt es bislang nur ungenügende Dokumentationen hinsichtlich der Regelmäßigkeit der bevölkerungsweiten T2D-Screeningaktivitäten. Da nationale Gesundheitssysteme vermehrt auf T2D-Screenings setzen, werden wir wohl in naher Zukunft Antworten auf einige verbleibende Forschungsfragen erhalten, um die Vor- und Nachteile des Screenings vollständig beurteilen zu können.

Schlüsselwörter

Typ-2-Diabetes · Vorteile · Identifizierung . Lebensstil $\cdot$ Interventionen

\section{Unsolved questions related to T2D screening}

One of the main current debates is related to which invasive screening test to use as the second step after non-invasive risk score in the T2D risk assessment. The classification of diabetes and other disorders of glucose metabolism are based on the definitions of the World Health Organization (WHO) [25, 46] and the American Diabetes Association
(ADA) [47]. There is some disagreement with regard to recommended diagnostic tests between the WHO and ADA (- Tab. 2). Although the ADA backs the use of $\mathrm{HbAlc}$ as the primary diagnostic test for diabetes mellitus (DM) [47], the WHO uniquely recommends an OGTT $[46,48]$. The OGTT is considered to be the gold standard test for screening and diagnosis [46, 48], as it takes into account both fasting and post-prandial glucose abnormalities. A standardized 


\begin{tabular}{|c|c|c|c|c|c|}
\hline & Test & WHO & & ADA & \\
\hline \multirow[t]{3}{*}{ Diabetes } & $\mathrm{HbA} 1 \mathrm{c}$ & Not recommended & & $\geq 6.5 \%$ & (48 mmol/l) \\
\hline & FPG & $\geq 7.0 \mathrm{mmol} / \mathrm{l}$ & $(\geq 126 \mathrm{mg} / \mathrm{dl})$ & $\geq 7.0 \mathrm{mmol} / \mathrm{l}$ & $(\geq 126 \mathrm{mg} / \mathrm{dl})$ \\
\hline & $2 \mathrm{hPG}$ & $\geq 11.1 \mathrm{mmol} / \mathrm{l}$ & ( $\geq 200 \mathrm{mg} / \mathrm{dl}$ ) & $\geq 11.1 \mathrm{mmol} / \mathrm{l}$ & $(\geq 200 \mathrm{mg} / \mathrm{dl})$ \\
\hline \multirow{3}{*}{$\begin{array}{l}\text { Impaired } \\
\text { glucose } \\
\text { tolerance }\end{array}$} & FPG & $<7.0 \mathrm{mmol} / \mathrm{l}$ & $(<126 \mathrm{mg} / \mathrm{dl})$ & $<7.0 \mathrm{mmol} / \mathrm{l}$ & $(<126 \mathrm{mg} / \mathrm{dl})$ \\
\hline & or & & & & \\
\hline & $2 \mathrm{hPG}$ & $\begin{array}{l}\geq 7.8- \\
<11.1 \mathrm{mmol} / \mathrm{l}\end{array}$ & $\begin{array}{l}(\geq 140- \\
<200 \mathrm{mg} / \mathrm{dl})\end{array}$ & Not required & \\
\hline \multirow{3}{*}{$\begin{array}{l}\text { Impaired } \\
\text { fasting } \\
\text { glucose }\end{array}$} & FPG & $6.1-6.9 \mathrm{mmol} / \mathrm{l}$ & $(110-125 \mathrm{mg} / \mathrm{dl})$ & $5.6-6.9 \mathrm{mmol} / \mathrm{l}$ & $(100-125 \mathrm{mg} / \mathrm{dl})$ \\
\hline & or & & & & \\
\hline & $2 \mathrm{hPG}$ & $<7.8 \mathrm{mmol} / \mathrm{l}$ & $(<140 \mathrm{mg} / \mathrm{dl})$ & Not required & \\
\hline
\end{tabular}

FPG fasting plasma glucose, 2 hPG 2-h post-load plasma glucose

OGTT is performed in the morning after an overnight fast $(8-14 \mathrm{~h})$. One blood sample should be taken before, and one 120 min after intake of $75 \mathrm{~g}$ of glucose dissolved in $250-300 \mathrm{ml}$ of water for $5 \mathrm{~min}$ (note that the timing of the test begins when the patient starts to drink).

The 2-h plasma glucose test in an OGTT provides a sensitivity of $97 \%$, with a specificity of $100 \%$ [49]. To diagnose DM, a confirmatory laboratory glycemic test (FPG, casual PG, HbAlc or $2 \mathrm{hPG}$ in a $75-\mathrm{g}$ OGTT) is necessary on another day in all cases in the absence of unequivocal hyperglycemia accompanied by acute metabolic decompensation. Repeat confirmatory testing on another day may be considered in the absence of symptoms. The HbAlc test, on the other hand, provides a retrospective average of glycemic control for the previous 3 months, by measuring the binding glucose to hemoglobin during the life span of red blood cells. A blood sample is easy to collect, as the HbAlc test does not require individuals to fast and there is practically no diurnal variation in HbA1c. In an analysis of three ethnically varied US databases, the proposed ADA diagnostic criteria for diabetes (HbAlc $\geq 6.5 \%$ ) failed to detect $70 \%$ of individuals with diabetes and 71-94\% with abnormal glucose tolerance. However, the $\mathrm{HbA} 1 \mathrm{c}$ resulted in more normal diagnoses than the OGTT [50]. A study conducted in a Spanish population [51] revealed that defining diabetes by a single $\mathrm{HbA1c}$ measurement resulted in a dramatic decrease in DM prevalence $(1.3 \%)$, particularly in comparison with diabetes defined by $2 \mathrm{hPG}(8.6 \%)$, but was also significant with regard to FPG $(2.8 \%)$. In the DPS the sensitivity of the HbAlc $\geq 6.5 \%$ ( $\geq 48 \mathrm{mmol} / \mathrm{mol}$ ) as a diagnostic criterion for T2D was $35 \%$ (95\% CI 24-47\%) in women and $47 \%$ (95\% CI 31-64\%) in men, compared with diagnosis based on two consecutive OGTTs [52]. Of those with T2D diagnosis based on two OGTTs during the DPS follow-up, $60 \%$ would have remained undiagnosed if diagnosis had been based on the HbAlc $\geq 6.5 \%$ ( $\geq 48 \mathrm{mmol} / \mathrm{mol}$ ) criterion.

In summary, the main problem with the $\mathrm{HbA1c}$ is that it has a low sensitivity in predicting DM, as it is a secondary phenomenon after high glucose in blood circulation. Thus, HbA1c values $<6.5 \%$ do not exclude DM that may be detected by FPG or 2 hPG [48, 50-52]. Thus, the diagnosis will be delayed. It is important to mention that the diagnosis of DM or abnormal glucose tolerance depends on whether FPG is measured alone or combined with a $2 \mathrm{hPG}$ value of an OGTT [53]. A normal FPG reflects an ability to maintain adequate basal insulin secretion in combination with hepatic insulin sensitivity sufficient to control hepatic glucose output. A post-load glucose level within the normal range requires an appropriate insulin secretory response and adequate insulin sensitivity in peripheral tissues. Thus, an individual with IFG in the fasting state may have undetected IGT or even DM. The usual argument in favor of a FPG or an HbAlc over a $2 \mathrm{hPG}$ is primarily related to feasibility or practicability and not scientific evidence. The WHO criteria are based on fasting plasma glucose (FPG) and 2hPG concentrations, and recommend the use of an OGTT in the absence of overt hyperglycemia $[46,48]$. The ADA criteria encourage the use of $\mathrm{HbAlc}$, fasting glycaemia, and, as a third option, possibly OGTT [47]. Recently, the EUROASPIRE IV, a cross-sectional survey in 24 European countries of patients $(n=4,004)$ aged 18-80 years with coronary artery disease, but with no reported history of diabetes, revealed that in patients with established coronary artery disease the OGTT identifies the largest number of patients with previously undiagnosed diabetes and should be the preferred test when assessing the glycemic state of such patients [54].

It is commonly agreed that there is no perfect diagnostic test for T2D. Although the OGTT is inconvenient and time-consuming, requires overnight fasting and its social acceptance may be poor, the fasting blood glucose test lacks sensitivity. So does HbAlc testing, which costs more than simple plasma glucose measurement and will miss many people who are identified as diabetic by an OGTT. Therefore, HbAlc cannot be applied in a large part of the world. The advantages and disadvantages of the HbAlc and the OGTT are presented in - Tab. 3.

Another unsolved issue is to define the optimal time interval between screening activities. Very little scientific information is available on the appropriate frequency of screening $[55,56]$. The optimal interval between screening examinations is the one at which the prevalence of undiagnosed cases reaches the prevalence of such cases at the previous screening, and the cost-effectiveness is the same for each screening effort [57]. Davies et al. studied whether a screening program for diabetes repeated after an interval of 30 months in 3,200 patients registered at a general clinic is worthwhile, both in terms of yield of new cases and continued high response rate [55]. The repeat screening response rate was somewhat lower than the initial response rate(73vs. $79 \%$ ). Furthermore, little information is available regarding the attendance for an OGTT after a positive screening test. Although Davies et 
Tab. 3 Advantages and disadvantages of assays for glucose and $\mathrm{HbA1c}$ testing. (Adapted from [48])

\begin{tabular}{|lll}
\hline & Glucose & HbA1c \\
\hline $\begin{array}{l}\text { Patient preparation be- } \\
\text { fore collection of blood }\end{array}$ & $\begin{array}{l}\text { Stringent requirements if mea- } \\
\text { sured for diagnostic purposes }\end{array}$ & None \\
\hline Processing of blood & $\begin{array}{l}\text { Stringent requirements for rapid } \\
\text { processing, separation and stor- } \\
\text { age of plasma or serum at a } \\
\text { minimum of } 4^{\circ} \mathrm{C}\end{array}$ & $\begin{array}{l}\text { Avoid conditions for more than } \\
12 \mathrm{~h} \text { at temperatures }>23^{\circ} \mathrm{C} . \\
\text { Otherwise keep at } 4{ }^{\circ} \mathrm{C} \text { (stability } \\
\text { for a minimum of } 1 \text { week) }\end{array}$ \\
\hline Measurement & Widely available & Not readily available worldwide \\
\hline Standardization & $\begin{array}{l}\text { Standardized to reference } \\
\text { method procedures }\end{array}$ & $\begin{array}{l}\text { Standardized to reference } \\
\text { method procedures }\end{array}$ \\
\hline Routine calibration & Adequate & Adequate \\
\hline Interferences: illness & $\begin{array}{l}\text { Severe illness may increase } \\
\text { glucose concentration }\end{array}$ & $\begin{array}{l}\text { Severe illness may shorten red- } \\
\text { cell life and artifactually reduce } \\
\text { HbA1c values }\end{array}$ \\
\hline Hemoglobinopathies & $\begin{array}{l}\text { Few problems unless the patient } \\
\text { is ill }\end{array}$ & $\begin{array}{l}\text { May interfere with measurement } \\
\text { in some assays }\end{array}$ \\
\hline Hemoglobinopathy traits & No problems & Most assays are not affected \\
\hline Affordability & $\begin{array}{l}\text { Affordable in most low- and } \\
\text { middle-income country settings }\end{array}$ & $\begin{array}{l}\text { Unaffordable in most low- and } \\
\text { middle-income country settings }\end{array}$ \\
\hline
\end{tabular}

al. reported compliance of $93 \%$ following a positive screening test, only approximately half of the high-risk individuals invited to an OGTT turned up at the laboratory in the DEMOJUAN project in Colombia [56]. The reasons may be partly related to a time constraint, as the test requires attendance at the laboratory in the morning and takes at least $2 \mathrm{~h}$, which may be difficult to arrange for people working during the daytime. Thus, it is a future challenge to develop a strategy to motivate people identified as being at a high risk of T2D to attend the diagnostic laboratory test. Novel strategies, such as a recently developed home-based OGTT test, may improve compliance [58].

Several questions remain to be answered, for instance, as to how to ensure periodic screening, how often screening should occur, and the frequency of attendance for a laboratory test followed by a positive screening test.

It would be very useful to have information on the long-term benefits of T2D screening programs. However, only little information is available $[59,60]$. In the only real diabetes screening study, the ADDITION (Anglo-Danish-Dutch study of intensive treatment in people with screen detected diabetes in primary care) trial, one-third of the practice population, aged 40 to 65 years, was screened by an OGTT between 1990 and 1992
[60]. The study participants were thereafter invited for repeat screening during 1994-1996 and 2000-2002. The other two-thirds of the study population were not initially followed up, but a randomly selected subsample (50\%) was invited for diabetes screening between 2000 and 2002. The general practitioners were informed of the screening results and were free to apply whatever treatment they considered appropriate. This study revealed after 13-year follow-up that there were no differences in cardiovascular outcomes or self-reported health status. The ADDITION-Cambridge trial was not a screening trial, but compared intensive intervention with standard care in people found to have undiagnosed diabetes by screening [59]. Uptake was lower if people had to have OGTTs, or if screening involved blood tests on more than one visit. However, they found that the uptake of blood glucose testing was improved if people were made aware in advance that they were at a high risk. However, after 10 years of follow-up, there was no reduction in cardiovascular, diabetes-related or total mortality events between the intervention group and the control group. It has been suggest that these results might be explained by improvements in standard care, especially as the treatment effect of blood pressure and cholesterol levels in the standard- care arm were similar to those in the intervention arm.

Any study assessing the long-term benefits of screening needs to be checked for lead-time bias. If it is possible to diagnose T2D earlier, but not to improve survival after diagnosis, the screening program will have an over-representation of earlier diagnosed patients, whose survival will be increased by exactly the amount of time their diagnosis was advanced by the screening program. If no intervention is provided in cases identified by a screening program, individuals will live exactly as long as they would without the screening program. Thus, a screening program that does not provide interventions for those at a high risk does not make much sense at all and may be even unethical. With regard to cost-effectiveness, a systematic literature review pointed out that screening for T2D and IGT, with appropriate intervention for those with IGT in an aboveaverage-risk population aged 45 , seems to be cost effective [61]. However, the cost-effectiveness of a policy of screening for diabetes alone, which offered no intervention to those with IGT, is still uncertain.

Only a few studies have studied the short- or long-term impact of diabetes screening programs. Studies assessing the long-term consequences of a diabetes screening program on psychological harms agree that there is no significant impact on anxiety, depression or qualityof-life subscales [62-69]. A recent study including 15 practices (10 screening, 5 controls) in the ADDITION-Cambridge trial in the east of England recruited 7,380 adults (aged 40-69) in the top fourth for risk of having undiagnosed T2D [62]. To our knowledge, this is the only trial to include a control group at a similar risk of having undiagnosed T2D. They found no significant differences in any of the five outcome measures (state anxiety, anxiety, depression, diabetes-specific worry, and self-rated health) between the screening attenders and control participants at the initial random blood glucose test, or between those invited for screening and controls at 3-6 months and 12-15 months. These results are in line with a recent meta-analysis of 12 studies, 
which revealed no significant impact on longer term anxiety, depression or quality-of-life subscales [70].

Only a few studies exist on the shortterm emotional impact of screening [63, 71]. In a randomized controlled trial in two general practices in the UK, people at a high risk of having undiagnosed T2D were assigned to either an invited or a non-invited group [63]. Six weeks after the last contact (either test or invitation), a questionnaire was sent to all participants, including those who were not originally invited, assessing attendance, anxiety, self-rated health and diabetes illness perceptions. Invited participants were more anxious than those who had not been invited and those diagnosed with diabetes were considerably more anxious than those classified as being free of diabetes. Furthermore, non-attenders had a lower mean emotional representation sub-scale than attenders. Thus, predicting an individual's risk of illness seemed to be associated with an increase in shortterm anxiety and depression [71].

Another important question in T2D screening is whether people diagnosed as being at a high risk of T2D are more likely to change their lifestyle than people who are unaware of their risk or whether a negative test may have an adverse shift in health behaviors. Results from the Cambridge MRC group found that screening for T2D is unlikely to cause an adverse shift in the population distribution of plasma glucose and cardiovascular risk, following an increase in unhealthy behaviors arising from false reassurance among people who have a negative screening outcome [72]. Moreover, the Hoorn study showed that the group with high-risk scores, but who did not have diabetes on glucose testing, had a risk of CVD almost as high as that in individuals who were glycaemia-positive, proposing that it might be of greater public health benefit to intervene in the entire screen-positive group than only in the relatively small group with increased glucose concentration in the subsequent laboratory tests [73].

\section{Conclusions}

T2D is inflicting a large economic burden on health-care systems all around the world. Considering that validated and low-cost T2D risk assessment tools exist, and that the current evidence has shown that T2D can be prevented by lifestyle interventions, T2D screening in the population may be justified. However, future studies need to assess the long-term impact of T2D screening on health outcomes such as CVD and psycho-neurological effects. Moreover, no information is available regarding the readiness and the capacity of the healthcare facilities and health-care staff to implement screening activities and subsequent interventions among high-risk individuals. After all, lifestyle modifications are not usually included in the tasks of health-care personnel. People who are at a high risk must themselves make necessary lifestyle changes, and there are other people outside the traditional health sector who may be able to help them with issues of healthy diet and physical activity. Also, there is a lack of evidence on the periodicity of population-wide screening activities. As more and more national health-care systems are implementing T2D screening activities, we may in the near future receive answers to some of the remaining research questions to fully assess the benefits and disadvantages of screening.

\section{Corresponding address}

\section{N. C. Barengo}

Department of Public Health, Clinicum hallinto, University of Helsinki

Haartmaninkatu 8, 00014 Helsingin yliopisto, Finland

noel.barengo@gmail.com

\section{Compliance with ethical guidelines}

Conflicts of interest. N. C. Barengo and J. O. Tuomilehto state that there are no conflicts of interest.

The accompanying manuscript does not include studies on humans or animals.

\section{References}

1. International Diabetes Federation (2015) IDF Diabetes, 7 ed. International Diabetes Federation, Brussels, Belgium. http://www.diabetesatlas.org

2. Williams R, Van Gaal L, Lucioni C (2002) Assessing the impact of complications on the costs of Type II diabetes. Diabetologia 45:13-17

3. Tuomilehto J, Rastenyte D, Qiao Q et al (2004) Epidemiology of macrovascular disease and hypertension in diabetes mellitus. In: De Fronzo RA, Ferrannini $E$, Keen $\mathrm{H}$, Zimmet $\mathrm{P}$ (eds) International Textbook of Diabetes Mellitus, 3rd edn. John Wiley \& Sons, Milan, pp 1345-1370

4. Manuel D, Schultz S (2004) Health-related quality of life and health-adjusted life expectancy of people with diabetes mellitus in Ontario, Canada, 1996-1997. Diabetes Care 27:407-414

5. Lee IM, Shiroma EJ, Lobelo F (2012) Effect of physical inactivity on major non-communicable diseases worldwide: an analysis of burden of disease and life expectancy. Lancet 380(9838):219-229

6. Barengo NC, Antikainen R, Peltonen M et al (2013) Changes in all-cause and cardiovascular disease mortality in three different Finnish population cohorts with and without diabetes. Int J Cardiol 168(5):4734-4738

7. Haffner SM, Stern MP, Hazuda HP et al (1990) Cardiovascular risk factors in confirmed prediabetic individuals. Does the clock for coronary heart disease start ticking before the onset of clinical diabetes? JAMA 263:2893-2898

8. Harris M, Klein R, Welborn T et al (1992) Onset of NIDDM occurs at least 4-7 years before clinical diagnosis. Diabetes Care 15:815-819

9. The DECODA Study Group (2003) Age-and sexspecific prevalence of diabetes and impaired glucose regulation in 11 Asian cohorts. Diabetes Care 26:1770-1780

10. The DECODE Study Group (2003) Age- and sexspecific Prevalences of diabetes and impaired glucose regulation in 13 european cohorts. Diabetes Care 26:61-69

11. Lindström J, llanne-Parikka P, Peltonen $M$ et al (2006) Sustained reduction in the incidence of type 2 diabetes by lifestyle intervention: the follow-up results of the Finnish diabetes prevention study. Lancet 368:1673-1679

12. Pan XR, Li GW, Hu YH et al (1997) Effects of diet and exercise in preventing NIDDM in people with impaired glucose tolerance. The Da Qing IGT and Diabetes Study. Diabetes Care 20:537-544

13. Ramachandran A, Snehalatha C, Mary Set al (2006) The Indian Diabetes Prevention Programme shows that lifestyle modification and metformin prevent type 2 diabetes in Asian Indian subjects with impaired glucose tolerance (IDPP-1). Diabetologia 49:289-297

14. Haffner SM, Stern MP, Hazuda HP et al (1990) Cardiovascular risk factors in confirmed prediabetic individuals. Does the clock for coronary heart disease start ticking before the onset of clinical diabetes? JAMA 263:2893-2898

15. Group TDECODES (2001) Glucose tolerance and cardiovascular mortality: comparison of fasting and 2-hour diagnostic criteria. Arch Intern Med 161:397-405

16. Qiao Q, Jousilahti P, Eriksson J et al (2003) Predictive properties of impaired glucose tolerance for cardiovascular risk are not explained by the development of overt diabetes during follow-up. Diabetes Care 26:2910-2914

17. Tuomilehto J, Lindström J, Eriksson JG et al (2001) Diabetes Prevention Program Research Group. 
Prevention of type 2 diabetes mellitus by changes in lifestyle among subjects with impaired glucose tolerance. NEngl J Med 344:1343-1350

18. Knowler WC, Barrett-Connor E, Fowler SE (2002) Reduction in the incidence of type 2 diabetes with lifestyle intervention or metformin. N Engl J Med 346:393-403

19. Kosaka K, Noda M, Kuzuya T (2005) Prevention of type 2 diabetes by lifestyle intervention: a Japanese trial in IGT males. Diabetes Res Clin Pract 67:152-162

20. Roumen C, Corpeleijn E, Feskens EJ et al (2008) Impact of 3-year lifestyle intervention on postprandial glucose metabolism: the SLIM study. Diabetes Med 25(5):597-605

21. Penn L, White M, Oldroyd J et al (2009) Prevention of type 2 diabetes in adults with impaired glucose tolerance: the European Diabetes Prevention RCT in Newcastle upon Tyne, UK. BMC Public Health 9:342

22. Lindström J, Peltonen M, Eriksson JG (2013) Finnish Diabetes Prevention Study (DPS). Improved lifestyle and decreased diabetes risk over 13 years: long-term follow-up of the randomised Finnish Diabetes Prevention Study (DPS). Diabetologia 56(2):284-293

23. Li G, Zhang P, Wang J et al (2008) The longterm effect of lifestyle interventions to prevent diabetes in the China Da Qing Diabetes Prevention Study: a 20-year follow-up study. Lancet 371(9626):1783-1789

24. KnowlerWC, Fowler SE, Hamman RF etal (2009) 10year follow-up of diabetes incidence and weight loss in the Diabetes Prevention Program Outcomes Study. Lancet 374(9702):1677-1686

25. Saito T, Watanabe M, Watanabe M (2011) Lifestyle modification and prevention of type 2 diabetes in overweight Japanese with impaired fasting glucose levels: a randomized controlled trial. Arch Intern Med 171(15):1352-1360

26. Association AD (2012) Diagnosis and Classification of Diabetes Mellitus- Position Statement. Diabetes Care 35(1):S64-S71

27. Davidson M, Schriger D, Peters A et al (1999) Relationship between fasting plasma glucose and glycosylated hemoglobin: potential for false positive diagnoses of type 2 diabetes using new diagnostic criteria. JAMA 281:1203-1210

28. The Expert Committee on the Diagnosis and Classification of Diabetes Mellitus (2003) Followup Report on the Diagnosis of Diabetes Mellitus. Diabetes Care 26:3160-3167

29. DECODE-study group (1998) Will new diagnostic criteria for diabetes mellitus change phenotype of patients with diabetes? Reanalysis of European epidemiological data. BMJ317:371-375

30. Lindström J, Tuomilehto J (2003) The Diabetes Risk Score: A practical tool to predict type 2 diabetes risk. Diabetes Care 26:725-731

31. Glumer C, Carstensen B, Sandbaek A (2004) Danish diabetes risk score for targeted screening: the inter99 study. Diabetes Care 27:727-733

32. Baan CA, Ruige JB, StolkRPetal (1999) Performance of a predictive model to identify undiagnosed diabetes in a health care setting. Diabetes Care 22:213-219

33. Stern MP, Williams K, Haffner SM et al (2002) Identification of persons at high risk for type 2 diabetes mellitus: do we need the oral glucose tolerance test? Ann Intern Med 136:575-581

34. Griffin SJ, Little PS, Hales CN et al (2000) Diabetes risk score: towards earlier detection of type 2 diabetes in general practice. Diabetes Metab Res Rev 16:164-171
35. Colagiuri S, Hussain Z, Zimmet P (2004) Screening for type 2 diabetes and impaired glucose metabolism: the Australian experience. Diabetes Care 27:367-371

36. Herman WH, Smith PJ, Thompson TJ et al (1995) A new and simple questionnaire to identify people at increased risk for undiagnosed diabetes. Diabetes Care 18:38238-38247

37. Kanaya AM, Wassel FCL, de Rekeneire $\mathrm{N}$ et al (2005) Predicting the development of diabetes in older adults: the derivation and validation of a prediction rule. Diabetes Care 28:404-408

38. Heikes KE, Eddy DM, Arondekar B et al (2008) Diabetes risk calculator: a simple tool for detecting undiagnosed diabetes and pre-diabetes. Diabetes Care 31:1040-1045

39. Balkau B, Lange C, Fezeu L et al (2008) Predicting diabetes: clinical, biological, and genetic approaches: data from the epidemiological study on the insulin resistance syndrome (Desir). Diabetes Care 31:2056-2061

40. Saaristo T, Peltonen M, Lindström J et al (2005) Cross-sectional evaluation of the Finnish Diabetes Risk Score: a tool to identify undetected type 2 diabetes, abnormal glucose tolerance and metabolic syndrome. Diab Vasc Dis Res 2:67-72

41. Franciosi M, De Berardis G, Rossi MCetal (2005) Use of the diabetes risk score for opportunistic screening of undiagnosed diabetes and impaired glucose tolerance: the IGLOO (Impaired Glucose Tolerance and Long-Term Outcomes Observational) study. Diabetes Care 28:1187-1194

42. Makrilakis K, Liatis S, Grammatikou S (2011) Validation of the Finnish diabetes risk score (FINDRISC) questionnaire for screening for undiagnosed type 2 diabetes, dysglycaemia and the metabolic syndrome in Greece. Diabetes Metab 2(37):144-151

43. Costa B, Barrio F, Cabré JJ et al (2012) Delaying progression to type 2 diabetes among high-risk Spanish individuals is feasible in real-life primary healthcare settings using intensive lifestyle intervention. Diabetologia 55(5):1319-1328

44. Rydén L, Standl E, Bartnik M et al (2007) Task Force on Diabetes and Cardiovascular Diseases of the European Society of Cardiology (ESC); European Association for the Study of Diabetes (EASD). Guidelines on diabetes, pre-diabetes, and cardiovascular diseases: The Task Force on Diabetes and Cardiovascular Diseases of the European Society of Cardiology (ESC) and of the European Association for the Study of Diabetes (EASD. Eur Heart J 28:88-136

45. Kengne PA, Beulens J, Peelen LM et al (2014) Noninvasive riskscores for prediction of type 2 diabete (EPIC-InterAct): a validation of existing models. Lancet Diabetes Endocrinol 2(1):19-29

46. Wilson JMG, Jungner G (1968) Principles and Practice of Screening for Disease. World Health Org, Geneva

47. World Health Organization (1999) WHO Consultation. Definition, diagnosis and classification of diabetes mellitus and its complications (1999) Part 1: diagnosis and classification of diabetes mellitus vol. Report no. 99.2. World Health Organization Geneva

48. World Health Organization (WHO) (2012) Consultation (2006). Definition and diagnosis of diabetes and intermediate hyperglycaemia. Diagnosis and classification of diabetes mellitus. Diabetes Care 35(Suppl 1):S64-71

49. American Diabetes Association Position Statement (2010) Diagnosis and classification of diabetes mellitus. Diabetes Care 33:S62-S69
50. World Health Organization (2011) Abbreviated report of a WHO consultation. Use of glycated hemoglobin $(\mathrm{HbA1c})$ in the diagnosis if diabetes mellitus. http://www.who.int/diabetes/ publications/diagnosis_diabetes2011/en/index. html

51. Harris MI (1993) Undiagnosed NIDDM: clinical and public health issues. Diabetes Care 16:642-652

52. Bennett CM, Guo M, Dharmage SC (2007) HbA1cas a screening tool for detection of type 2 diabetes: a systematic review. Diabet Med 24:333-343

53. Costa B, Barrio F, Cabre JJ et al (2011) Shifting from glucose diagnostic criteria to the new $\mathrm{HbA}(1 \mathrm{c})$ criteria would have a profound impact on prevalence of diabetes among a high-risk Spanish population. Diabet Med 28(10):1234-1237

54. Pajunen P, Peltonen M, Eriksson JG et al (2011) $\mathrm{HbA}(1 \mathrm{c})$ in diagnosing and predicting Type 2 diabetes in impaired glucose tolerance: the Finnish Diabetes Prevention Study. Diabet Med 28(1):36-42

55. (1999) Consequences of the new diagnostic criteria for diabetes in older men and women. DECODE Study (Diabetes Epidemiology: Collaborative Analysis of Diagnostic Criteria in Europe). Diabetes Care 22(10):1667-1671

56. Gyberg V, De Bacquer D, Kotseva K et al (2015) Screening for dysglycaemia in patients with coronary artery disease as reflected by fasting glucose, oral glucose tolerance test, and $\mathrm{HbA} 1 \mathrm{c}$ a report from EUROASPIRE IV-a survey from the European Society of Cardiology. Eur Heart J 36:1171-1177

57. Davies M, Day J (1994) Screening for noninsulindependent diabetes mellitus (NIDDM): how often should it be done? J Med Screen 1:78-81

58. Barengo NC, Acosta T, Arrieta A et al (2013) Screening for people with glucose metabolism disorders within the framework of the DEMOJUAN project (DEMOnstration area for primary prevention of type 2 diabetes, JUAN Mina and Barranquilla, Colombia). Diabetes Metab Res Rev. doi:10.1002/ dmrr.2462

59. Engelgau MM, Narayan KM, Herman WH (2000) Screening for type 2 diabetes. Diabetes Care 23(10):1563-1580

60. Facchinetti A, Sparacino G, Guerra S et al (2012) Real-time improvement of continuous glucosemonitoring accuracy: the smart sensor concept Diabetes Care 36(4):793-800

61. Rahman M,Simmons RK, Hennings SH(2012)Effect of screening for Type 2 diabetes on populationlevel self-rated health outcomes and measures of cardiovascular risk: 13-year follow-up of the Ely cohort. Diabet Med 29(7):886-892

62. Simmons RK, Echouffo-Tcheugui JB, Sharp SJ et al (2012) Screening for type 2 diabetes and population mortality over 10 years (ADDITIONCambridge): a cluster-randomised controlled trial. Lancet 380:1741-1748

63. Gillies CL, Lambert PC, Abrams KR et al (2008) Different strategies for screening and prevention of type 2 diabetes in adults: cost effectiveness analysis. BMJ 336(7654):1180-1185

64. Eborall HC, Griffin SJ, Prevost AT et al (2007) Psychological impact of screening for type 2 diabetes: controlled trial and comparative study embedded in the ADDITION (Cambridge) randomised controlled trial. Br Med J335(7618):486-493

65. Park P, Simmons RK, Prevost AT (2008) Screening for type 2 diabetes is feasible, acceptable, but associated with increased short-term anxiety: a randomised controlled trial in british general practice. BMC Public Health 8:350-359 
66. Adriaanse MC, Snoek FJ (2006) The psychological impact of screening fortype 2 diabetes. Diabetes Metab Res Rev 22:20-25

67. Skinner TC, Davies MJ, Farooqi AM et al (2005) Diabetes screening anxiety and beliefs. Diabet Med 22:1497-1502

68. Farmer AJ, Doll H, Levy JC et al (2003) The impact of screening for type 2 diabetes in siblings of patients with established diabetes. Diabet Med 20:996-1004

69. Thoolen BJ, de Ridder DT, Besing JM et al (2005) Psychological outcomes of patients with screendetected type 2 diabetes: the influence of time since diagnosis and treatment intensity. Diabetes Care 29:2257-2262

70. Edelman D, Harris AC, Olsen MK et al (2002) Impact of diabetes screening on quality of life. Diabetes Care 25:1022-1026

71. Adriaanse MC, Snoek FJ, Dekker JM et al (2004) No substantial psychological impact of the diagnosis of type 2 diabetes following targeted population screening: the Hoorn screening study. Diabet Med 21(9):992-998

72. Collins RE, LopezLM, Marteau TM (2001) Emotional impact of screening: a systematic review and meta-analysis. BMC Public Health 11:603

73. Park P, Simmons RK, Prevost AT et al (2008) Screening for type 2 diabetes is feasible, acceptable, but associated with increased short-term anxiety: a randomised controlled trial in british general practice. BMC Public Health 8:350-359

74. Shaw C, Abrams K, Marteau TM (1999) Psychological impact of predicting individuals' risks of illness: a systematic review. Soc Sci Med 49:1571-1598

75. Paddison CA, Eborall HC, Sutton S et al (2009) Are people with negative diabetes screening tests falsely reassured? Parallel group cohort study embedded in the ADDITION (Cambridge) randomised controlled trial. BMJ 339:b4535

76. Spijkerman A, Griffin S, Dekker J et al (2002) What is the risk of mortality for people who are screen positive in a diabetes screening programme but who do not have diabetes on biochemical testing? Diabetes screening programmes from a public health perspective. J Med Screen 9:187-190
Hirntod

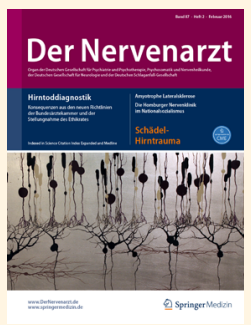

Seit Juli 2015

gelten für die Hirntoddiagnostik die neuen Richtlinien der Bundesärztekammer in ihrer 4. Fortschreibung. Der Focus der

Zeitschrift Der Nervenarzt wurde daher in der Ausgabe 02/2016 auf den Schwerpunkt "Hirntod“ gerichtet. Sie erhalten Informationen über die neuen Richtlinien und einen Überblick über den Stand der Diskussion zu diesem sensiblen Thema, das für alle Ärzte bei der Arbeit im Klinikalltag eine wichtige Rolle spielt.

- Kommentar zur Stellungnahme des Ethikrates

- Vierte Fortschreibung der Richtlinie zur Feststellung des irreversiblen Hirnfunktionsausfalls. Verfahrensabläufe und Neuerungen

- EEG und Evozierte Potentiale zum Irreversibilitätsnachweis der klinischen Ausfallssymptome des Gehirns

- Angiographische Verfahren zur Feststellung des zerebralen Zirkulationsstillstandes

- Organspende nach Herz- und Kreislauftod

Bestellen Sie diese Ausgabe zum Preis von 39,- EUR (zzgl. Versandkosten) bei Springer Customer Service Center Kundenservice Zeitschriften Haberstr. 7

69126 Heidelberg

Tel.: +49 6221-345-4303

Fax: +49 6221-345-4229

E-Mail: leserservice@springer.com

Suchen Sie noch mehr zum Thema? Mit e.Med, dem Online-Paket von Springer Medizin, können Sie schnell und komfortabel in über 600 medizinischen Fachzeitschriften recherchieren.

Weitere Infos unter

springermedizin.de/eMed.

\section{Schlaganfall}

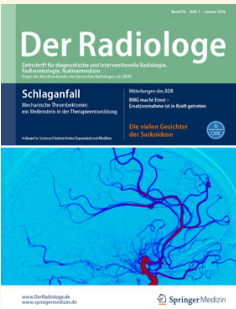

Bei akutem Schlaganfall ist die mechanische Thrombektomie ein Meilenstein in der Therapie. Neben einer adäquaten Bild-

gebung ist das Zeitmanagement absolut notwendig.

In Der Radiologe 1/2016 wird über Kenntnisse und Erfahrungen mit endovaskulären Prozeduren berichtet. Weiter erhalten Sie Hinweise auf die für die Erstversorgung wichtigen "Stroke Units" sowie Einblicke in weiterführende Therapien.

- Schlaganfall: Wie übersetzt man „Zeit ist Hirn" in klinische Praxis?

- Mechanische Thrombektomie - Studienlage und Technik

- Endovaskuläre Behandlung der Akuten Oklussion der Extrakraniellen Arteria Carotis

- "Pitfalls" bei mechanischer Rekanalisation

- Mobile Stroke Unit zur prähospitalen Schlaganfalltherapie

- Mechanische Thrombektomie Akutkomplikationen und Spätfolgen

- Intubation und Sedierung bei der endovaskulären Therapie des akuten Hirninfarkts

Bestellen Sie diese Ausgabe zum Preis von 49,- EUR zzgl. Versandkosten bei Springer Customer Service Center Kundenservice Zeitschriften

Haberstr. 7

69126 Heidelberg

Tel.: +49 6221-345-4303

Fax: +496221-345-4229

E-Mail: leserservice@springer.com

Suchen Sie noch mehr zum Thema? Mit e.Med, dem Online-Paket von Springer Medizin, können Sie schnell und komfortabel in über 500 medizinischen Fachzeitschriften recherchieren.

Weitere Infos unter

springermedizin.de/eMed. 